\title{
Use of Graphic Organizers in a Language Teachers' Professional Development
}

\author{
Chin-Wen Chien ${ }^{1}$ \\ ${ }^{1}$ Department of English Instruction, National Hsinchu University of Education, Hsinchu City, Taiwan \\ Correspondence: Chin-Wen Chien, Department of English Instruction, National Hsinchu University of Education, \\ Hsinchu City, Taiwan. Tel: 1-886-3-5213132. E-mail: chinwenc@ms24.hinet.net
}

Received: June 21, 2012 Accepted: July 12, 2012 Online Published: August 16, 2012

doi:10.5539/elt.v5n10p49 URL: http://dx.doi.org/10.5539/elt.v5n10p49

\begin{abstract}
Starting from 2009 academic year, the instructional coaches in a school district in a northwest American city began to provide Workshop II (pseudonym) to elementary school English teachers. This study aims to discuss the use of graphic organizers in English teachers' professional development. Different types of graphic organizers such as conceptual development charts, Venn diagrams, or T-charts, were used by the instructional coaches in Workshop II to help English teachers understand the academic language and lesson planning process. Moreover, English teachers were expected to implement these graphic organizers into their classroom practice and help their English learners understand academic language and content knowledge. The provision of graphic organizers helped the participating teachers learn and process the knowledge and concepts taught in Workshop II. Two participating teachers applied T-chart and bubble maps, two graphic organizers introduced in Workshop II, into their classroom practice. Suggestions on effectively use graphic organizers for both classroom practice and professional developments will be provided.
\end{abstract}

Keywords: graphic organizer, Workshop II, English teacher, professional development, academic language

\section{Introduction}

\subsection{Introducing the Issues}

Graphic organizers have been developed as a result of Ausubel's (1960) research on the benefits of using an advance organizer to enhance learners' acquisition of new knowledge. Graphic organizers are considered to have impact on students' learning, such as reading comprehension and recall (Boulware \& Jones, 2009; Merkley, 2000), math (Zollman, 2009), and science (Hawk, 1986). Graphic organizers help students organize and structure information and concepts as well as promote thinking about relationships between concepts. However, no studies have been conducted on the use and influence of graphic organizers on teachers' learning.

Starting from 2009 academic year, the instructional coaches in a school district in a northwest American city began to provide Workshop II (pseudonym) to elementary school English teachers. Workshop II was a twelve-hour course to support teachers in developing a better understanding of what academic language is and how to teach it. Different types of graphic organizers were used in Workshop II.

This study aims to discuss the use of graphic organizers in English teachers' professional development. The study discusses the following two issues. First, what, why, and how were graphic organizers used in the English teachers' professional development? Second, how were English teachers' attitude and responses to the use of graphic organizers in their professional development? Third, how and what did English teachers implement these graphic organizers into their classroom practice? Finally, suggestions on effectively use graphic organizers for both classroom practice and professional developments will be provided.

\subsection{Discussing Relevant Literature Review on Professional Development}

The evaluation and impacts of professional development on teacher change and student learning can be measured based on Guskey's criteria: participant learning, the organization's support and change, change in teacher knowledge skills and instructional pedagogy, teacher perception of student learning and changes in attitudes and beliefs of teachers (Guskey, 2000; Guskey 2002).

Effective professional development should include an assessment of student needs, assessment of teacher needs, 
and a focus on teaching practices that facilitate student learning (Abdal-Haqq, 1995; Barela, Fernandez, \& Hayes, 2005; England, 1998; Speck \& Knipe, 2001; Wilson \& Berne, 1999). When professional development is provided to teachers, it should be presented with practicability in mind. The new strategies should show change in the students' learning within a short time (Sparks, 1994). Teachers need to receive regular feedback on student learning outcomes, and continuous support and following-up is necessary after the initial training (Barela et al, 2005).

Moreover, effective professional development for language teachers must focus both on content knowledge and pedagogical skills (Eun, 2006; Wilson \& Berne, 1999). Teachers working with English learners have to be equipped with knowledge of both second language acquisition theories, and of the instructional strategies that enhance the English learning process. Olivia and Pawlas (2001) mention that materials provided in the professional development must be practical and not too theoretical. Teachers as practitioners want to apply what they have learned into their classroom practice immediately.

\subsection{Discussing Relevant Literature Review on Graphic Organizers}

Graphic organizers are "visual displays teachers use to organize information in a manner that makes the information easier to understand and learn" (Meyen, Vergason, \& Whelan, 1996, p. 132). A graphic organizer is a powerful instructional tool and strategy in vocabulary development (Smith, 2002; Teal, 2003), reading (Boulware \& Jones, 2009; Buschick, Shipton, Winner, \& Wise, 2007; Dye, 2000; Gabl, 2007; Merkley, 2000; Williams, Hall, Lauer, Stafford, Desisto, deCani, 2005), writing (Bulgren, Marquis, Lenz, Schumaker, \& Deshler, 2009; Nussbaum \& Schraw, 2007; Wallace, Pearman, Hail, \& Hurst, 2007), math (Ives, 2007; Zollman, 2009), complex thinking (Assaf, 2009; Gil-Garcia \& Villegas, 2003; Goodson, 2000), note taking (Fisher, 2001; Katayama \& Robinson, 2000; Robinson, Katayama, Beth, Odom, Hsieh, \& Vanderveen, 2006), and science (Hawk, 1986; DeMeo, 2007; Mackinnon, 2006; Stull \& Mayer, 2007). A graphic organizer provides an overview of materials to be learned; a reference point for putting new vocabulary and main ideas into orderly patterns; a cue for important information; a visual stimuli for written and verbal information; and a concise review tool.

However, Ben-David (2002) discovered that there was no significant difference for results between the comprehension assessment and traditional tests regarding the provision of eight weeks of instruction and assessments on using graphic organizers and linear note forms among sixteen seventh-grade learning disabled students. Therefore, Ben-David suggests that teachers should use graphic organizers, traditional notes, and tests in order to foster the development of comprehension.

Gil-Garcia and Villegas (2003) categorize knowledge graphic organizers into six types: description or simple listing, time/temporal sequence, definition and example, comparison and contrast, cause and effect, and problem solution. There are varieties of graphic organizers such as word web, T-chart, Venn diagram, Ogle's KWL (what you already knew, what you want to learn, what you learned) $(1986,2009)$, semantic webs, mind mapping, matrix, flow charts, problem solution map, character map, sequencing, etc. Zollman (2009) discovered that the implementation of Gould and Gould's (1999) "four corners and a diamond" in Figure 1 made dramatic improvements in middle school students' mathematics scores on open-response items. Similar to Gould and Gould's (1999) "four corners and a diamond," McMackin and Witherell (2005) and Wallace et al (2007) suggest using four corners in Figure 2 in writing because it helps writers generalize their thoughts across the curriculum to make meaningful connections between self, world, and other texts.

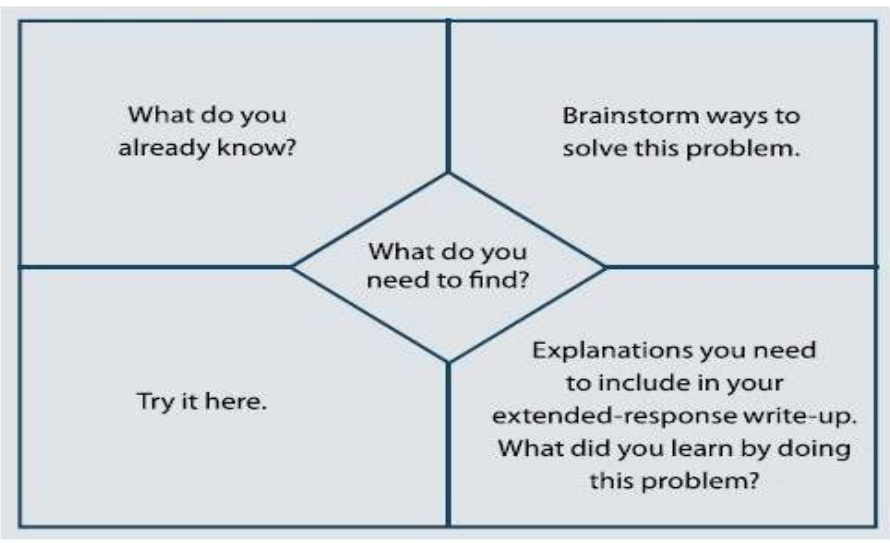

Figure 1. Four Corners and A Diamond 


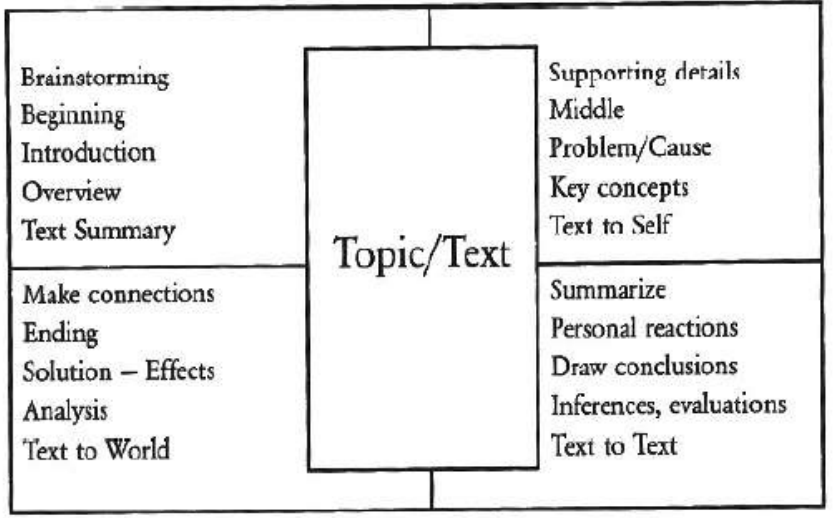

Figure 2. Four Corners

Scholars suggest the following steps in creating graphic organizers for reading: (1) analyze the learning task for words and concepts important for the student to understand, (2) arrange them to illustrate the interrelationships and patterns of organization, (3) evaluate the clarity of relationships as well as the simplicity and effectiveness of the visual, and (4) substitute empty slots for certain words in order to promote students' active reading (Dye, 2000; Merkley, 2000; Richardson \& Morgan, 1997; Roe, Stoodt, \& Burns, 1998; Ruddell, 1996).

The above studies reveal the impacts of graphic organizers on students' learning in content areas or reading. However, no scholars have studied the use and influence of graphic organizers on teachers' learning. Therefore, this study aims to discuss the use of graphic organizers in an elementary school English teachers' professional development and the influence of such professional development on teachers' classroom practice.

\section{Methods}

\subsection{Date Collection}

The data collection lasted from September 2009 to December 2010. The data collection in this study was divided into two stages. In stage one, the data mainly focused on workshops, so the data were collected when Workshop II were provided between fall 2009 and spring 2010. In stage 2, the data focused on ELL teachers' practice and use of graphic organizers and knowledge from Workshop II and the data was collected from October to December 2010.

The data in this study included: (1) documentation: Binders and PowerPoint files of Workshop II, (2) observational fieldnotes on the instructional coaches' design and delivery of Workshop II as well as two English teachers' classroom instruction, and (3) interviews on one instructional coach's the design and deliver of Workshop II and two English teachers' reactions and learning regarding the use of graphic organizers in Workshop II.

\subsection{Participants and Setting}

Snowball sampling was used in this study and it was defined by Merrian (1998) as involving "asking each participant or group of participants to refer you to other participants" (p. 63). I asked the instructional coach whom I did internship with to recommend me English teachers in her coaching school. The first participant was the instructional coach, Barbara. Barbara works under one program director and with other five instructional coaches and two consulting teachers. In fall 2010, she is assigned to be responsible for six elementary schools. Barbara designs and delivers professional development, co-plans with teachers, provides model lessons, observes teachers' instruction, designs and releases a monthly newsletter, provides related teaching materials and resources, and helps teachers understand the requirements of language proficiency levels of English Language Development.

Nicole is an English teacher in Clarke Elementary School (pseudonym). She had a master's degree in education, a teacher's certificate, and an English language learning (ELL) teacher's endorsement. She has participated in many professional development activities such as Guided Language Acquisition Development (GLAD), Sheltered Instruction Observation Protocol (SIOP), and Reading First. She began to teach since 2001. She 
teaches thirty students from kindergarten through fifth grades with a total of nine thirty-minute sessions every day.

The third participant is Rebecca. She received her teacher's certificate and ELL teacher's endorsement. She was a kindergarten classroom teacher for six years in two schools and she wanted to be a specialist. She became an English teacher in Mitchell Elementary School (pseudonym) two years ago. She serves 55 students from kindergarten through the fifth grade. She provides pull-out instruction or co-teaches with general education teachers in the classrooms for these students. Since Rebecca is just a brand-new English teacher, in addition to Workshop I and II, she did not have any training in teaching ELLs.

\subsection{Data Analysis}

Data were categorized into units of information. Once the data were coded, tables were constructed to summarize the data and to allow it to be checked for patterns. Two checks for trustworthiness were performed: triangulation and member checking. Qualitative researchers typically gather multiple forms of data, such as interviews, observations, and documents, rather than rely on a single data source (Creswell, 2009; LeCompte \& Schensul, 1999; Marshall \& Rossman, 2006). In this study triangulating multiple sources of data can add texture, depth, and multiple insights to an analysis, and it can enhance the validity or credibility of the results. Following data collection, I undertook member checking by reporting back preliminary findings to the English teachers and instructional coach, asking for critical comments on the findings, and (potentially) incorporating any critiques into the findings.

\section{Results}

The findings were discussed in terms of the use of graphic organizers in Workshop II and English teachers' attitude toward and use of graphic organizers.

\subsection{Use of Graphic Organizers in Workshop II}

Graphic organizers were designed and integrated into Workshop II including synonym bubble map, conceptual development chart, summarizing, Venn diagram, T-chart, and drawing conclusions. Barbara hoped teachers would apply these graphic organizers into their classroom practice.

On the first day of Workshop II, teachers were asked to write a word to describe their fellow teacher on the synonym bubble map as "I am _.." Teachers were asked to introduce themselves by sharing the information on the synonym bubble map in Figure 3. Barbara reminded teachers that bubble map could be used for science, word choice, or social science.

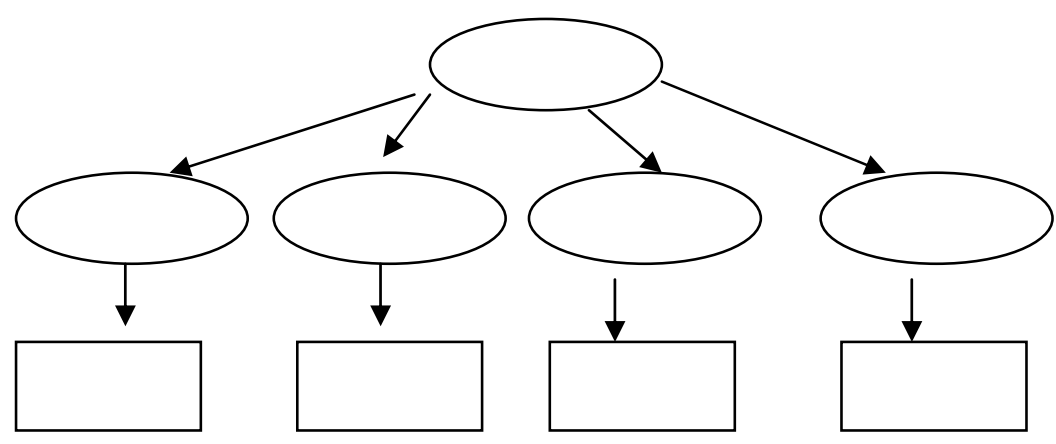

Figure 3. Synonym Bubble Map

By the end of the first day workshop, teachers were asked to summarize four key points they learned from that day's workshop by completing two sentences "The main idea today was..." and "Something I want to try is..." on the graphic organizers in Figure 4. 


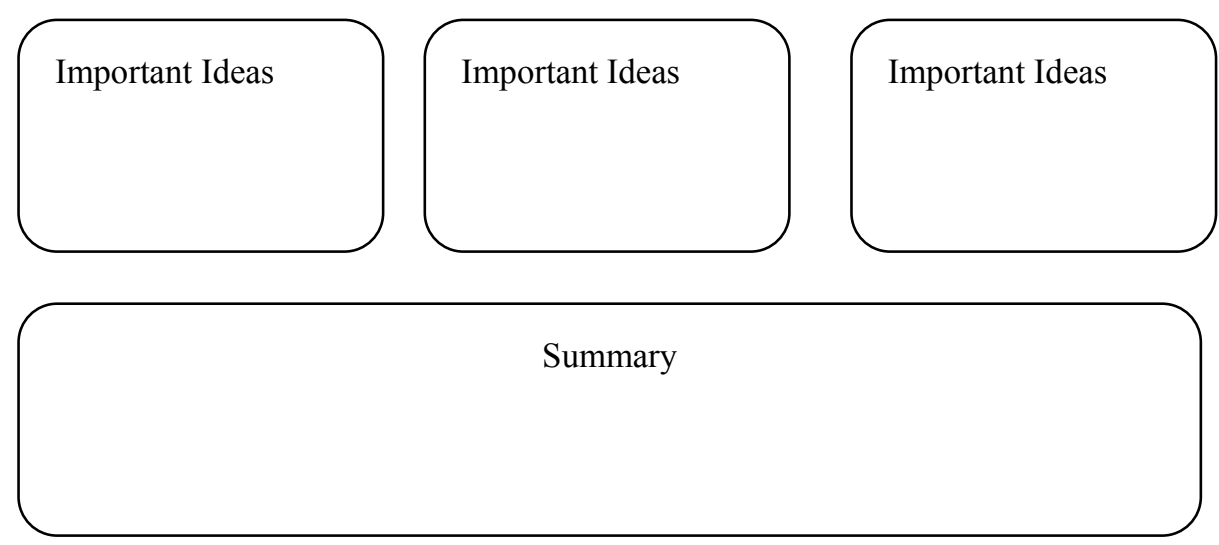

Figure 4. Summarizing

On the third day of Workshop II, Barbara introduced a T-chart in Figure 5 to be used for comparing and contrasting. T-chart involves writing a big $\mathrm{T}$ and putting comparing categories on the opposite side of the vertical line. After the T-chart was completed, the teachers were asked to evaluate the stories in the book based on the criteria they listed on the T-chart. She also suggested that teachers could use Venn Diagram for compare and contrast as in Figure 6.

\section{Fiction} Non/Fiction
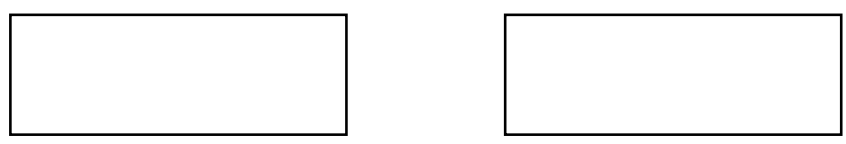

Figure 5. Attribute T-Chart

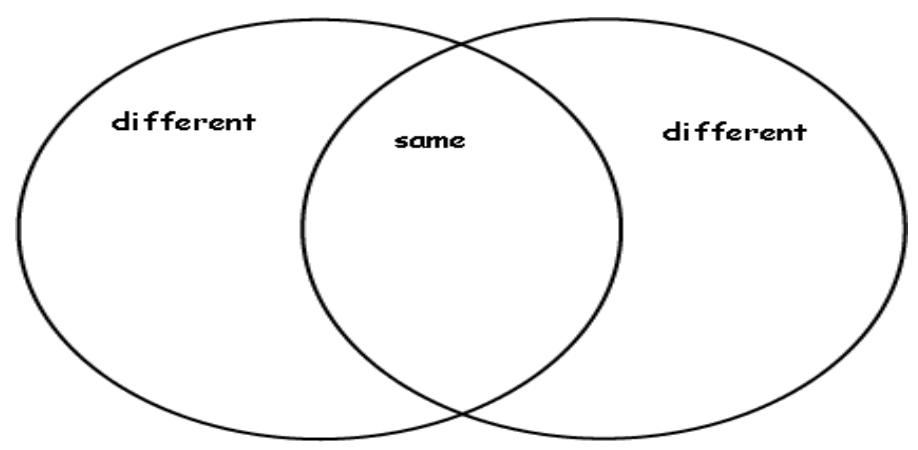

Figure 6. Compare/Contrast

Barbara also introduced graphic organizers for drawing conclusion as in Table 1 and bubble map as in Figure 7 for classroom instruction.

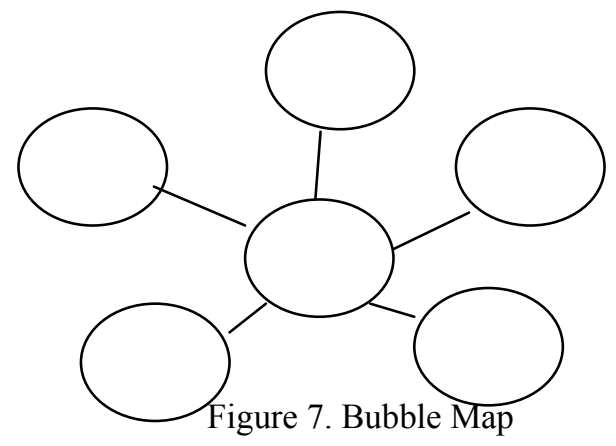


Table 1. Drawing Conclusions

\begin{tabular}{lll}
\hline Text clues & What I already know & My conclusion \\
\hline
\end{tabular}

Barbara gave a teaching demonstration on reading and writing workshops. She modeled how to use the graphic organizer "Taxonomy A-Z" as in Table 2 as an assessment tool to evaluate students' understanding of seahorses. She asked teachers one question "Where do seahorses live?" The teachers replied "ocean" and she wrote "ocean" next to the letter "o." Barbara also reminded teachers that this Taxonomy A-Z could be used as a review for any subject.

Table 2. Taxonomy A-Z

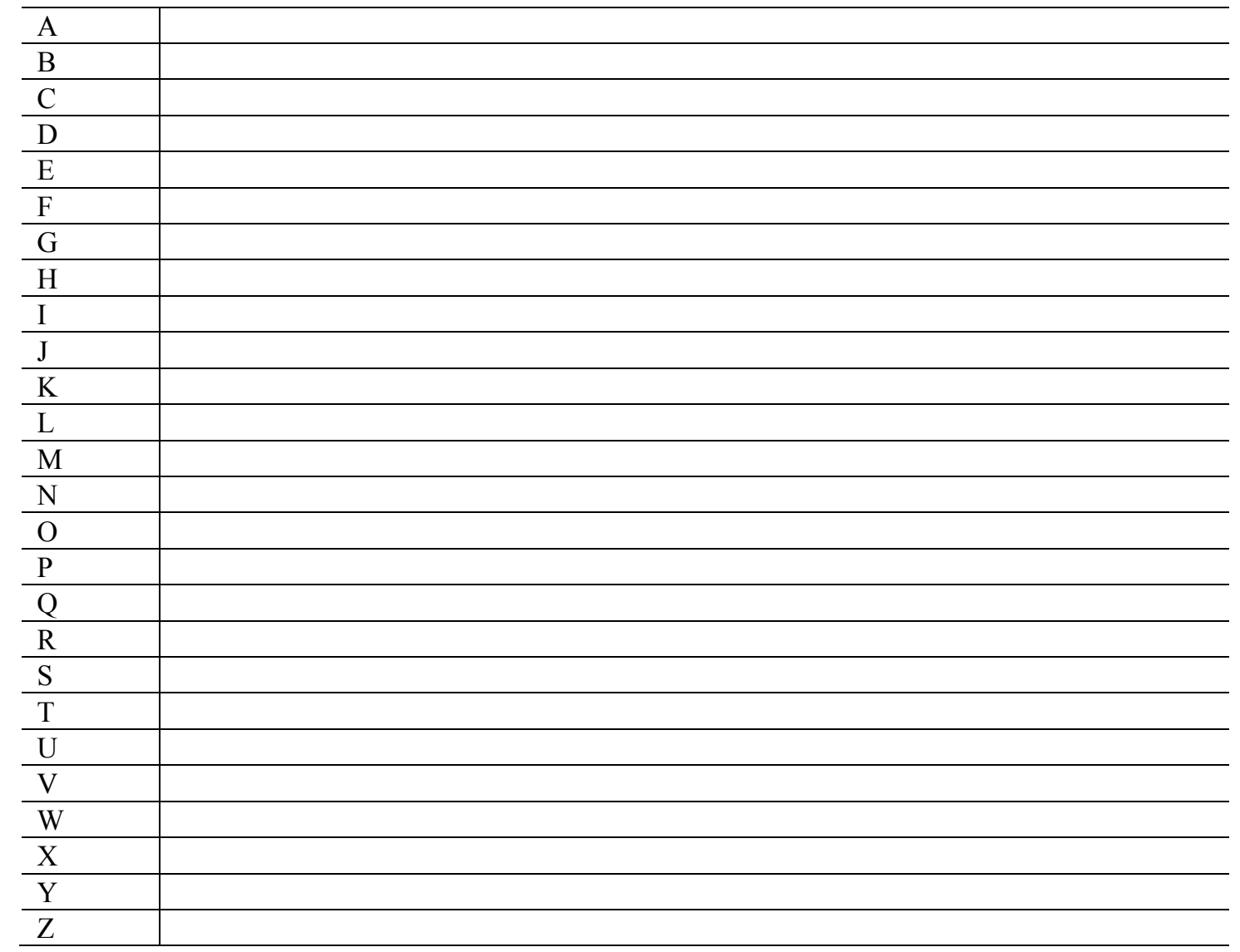

\subsection{English Teachers' Attitude Toward and Use of Graphic Organizers}

Nichole thought that the provision of graphic organizers helped her learn and process the knowledge. She said, "I felt like that it was super organized and super structured... they were a lot of modality, visual aids, visual models and maps which for me, that's really critical."

After Workshop II, both Nichole and Rebecca integrated some graphic organizers into their classroom practice. After reading books about fish and mammals, Nichole made a big chart to assess the knowledge her students remembered. She asked them to compare and contrast the facts about animals in terms of their skeletons, body temperature, breathing, skin, offspring, and interesting facts as in Table 3. When students forgot the fact, she asked them to find information in the books they just read.

Rebecca used bubble maps a lot when she asked learners to summarize the main ideas of the stories. Rebecca reviewed the character traits and taught a sentence "I think _(a character) is _(adjective), because _(facts)." Students had to use this sentence stem to describe the character traits in Rylant's (1997) Poppleton. Students first described the characters orally and she wrote down what they said by drawing a character mapping as in Figure 8 . 
Table 3. Comparison and Contrast on Animal Facts

\begin{tabular}{lll}
\hline \multicolumn{1}{c}{ Fish } & Mammals & Reptiles \\
\hline Skeletons & & \\
\hline Body temperature & \\
\hline How they breathe & \\
\hline Skin, covering & \\
\hline How babies are born & \\
\hline Interesting facts
\end{tabular}

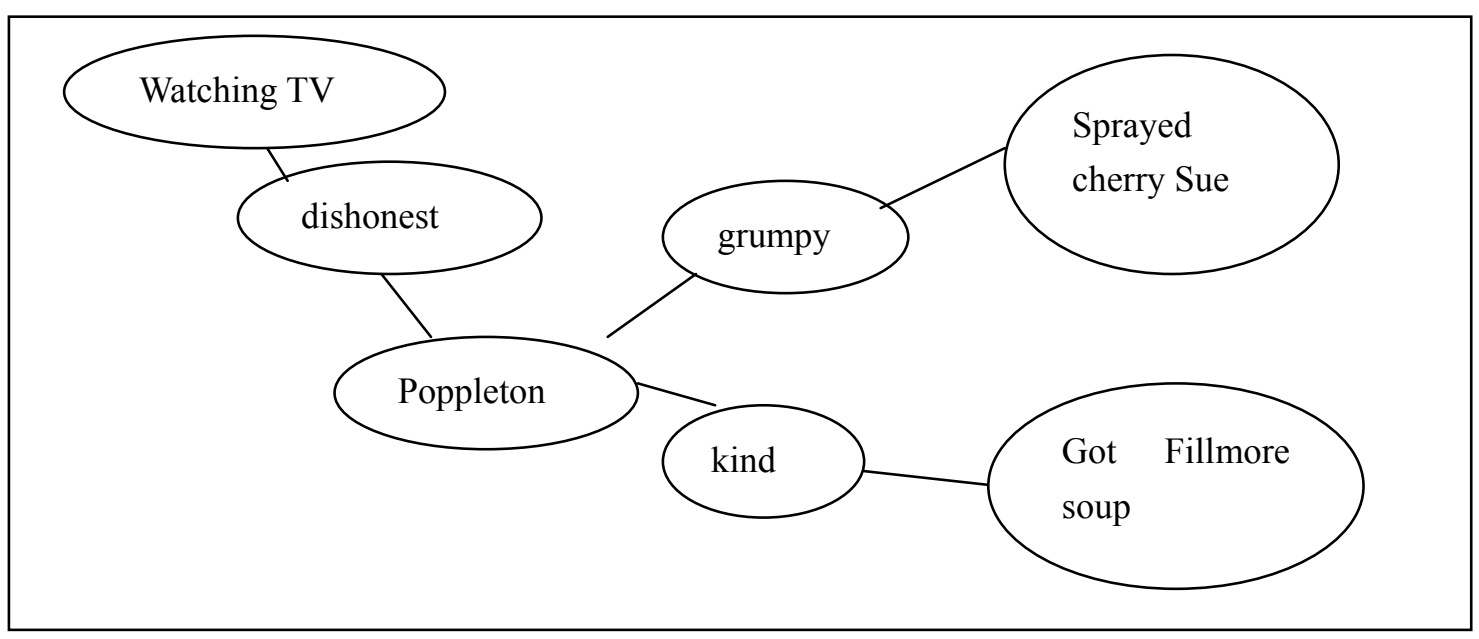

Figure 8. Character Traits on Rylant's (1997) Poppleto

\section{Discussion}

This study aimed to discuss the use of graphic organizers in language teachers' professional development on academic language. Barbara's intention of introducing different types of graphic organizers to language teacher in Workshop II were to help English teachers understand theoretical concepts of academic language and lesson planning process. Moreover, she also expected English teachers to implement these graphic organizers into their classroom practice and help their English learners understand academic language and content knowledge. Barbara used different types of graphic organizers including synonym bubble maps, conceptual development charts, summarizing, Venn diagrams, T-charts, and drawing conclusions in Workshop II. English teachers introduced themselves through synonym bubble maps, compared and contrasted key concepts via T-chart, summarize and conclude the main ideas on the lessons they learned through T-charts, or Taxonomy A-Z.

English teachers, particularly Nichole, liked Barbara's use of graphic organizers in Workshop II, because she thought that the provision of graphic organizers helped her learn and process the knowledge. English teachers began to implement these graphic organizers into their classroom practice. Nichole used T-chart for reviewing animal facts and Rebecca used mind mapping for summarizing stories.

More graphic organizers, such as mind-mapping, KWL chart, idea wheel, spider map, flow chart, fishbone, Y-chart, PWI (plus, minus, interesting) chart etc, could be integrated in Workshop II. So English teachers can employ these appropriate varieties of graphic organizers in their classroom to help students classify ideas, communicate more effectively, problem solve, brainstorm, or structure writing projects.

This study focuses on the use of different graphic organizers in an elementary school English teachers' professional development and how English teachers put those graphic organizers into practice. A follow-up study could be conducted on discussing how the influence of these two teachers' implications on graphic organizers on their learners' reading comprehension.

\section{References}

Abdal-Haqq, I. (1995). Making time for teacher professional development. Washington, DC: ERIC Clearinghouse on Teaching and Teacher Education. Retrieved from http://www.ericdigests.org/1997-2/time.htm 
Assaf, M. A. (2009). Teaching and thinking: A literature review of the teaching of thinking skills. ERIC Document 505029. Washington, DC: ERIC Clearinghouse on Teaching and Teacher Education. Retrieved from http://www.eric.ed.gov/PDFS/ED505029.pdf

Ausubel, D. P. (1960). The use of advanced organizers in the learning and retention of meaningful behavior. Journal of Educational Psychology, 51, 267-272. http://dx.doi.org/10.1037/h0046669

Barela, E., Fernandez, A., \& Hayes, K. (2005). Research in best practices: Latino academic achievement case study (laacs) (Planning, Assessment, and Research Division Report No. 244). Los Angeles, CA: Los Angeles Unified School District. $\quad$ Retrieved from http://notebook.lausd.net/pls/ptl/docs/PAGE/CA_LAUSD/FLDR_ORGANIZATIONS/FLDR_PLCY_RES _DEV/PAR_DIVISION_MAIN/RESEARCH_UNIT/PROJECTST/PERB_LEARNING_INSTRUCTIŌN_S TUDIES/LATINO_ACHIEVE_GAP/LAACS\%20REPORT.PDF

Ben-David. (2002). Enhancing comprehension through graphic organizers (Unpublished master's thesis). Kean University, New Jersey, the United States.

Boulware, B., \& Jones, C. (2009). Book characters' choices: Helping students interpret their action. Childhood Education, 85(3), 178-G.

Bulgren, J. A., Marquis, J. G., Lenz, B. K., Schumaker, J. B., \& Deshler, D. D. (2009). Effectiveness of question exploration to enhance students' written expression of content knoweldge and comprehension. Reading \& Writing Quarterly, 25(4), 271-289. http://dx.doi.org/10.1080/10573560903120813

Buschick, M. E., Shipton, T., A., Winner, L. M., \& Wise, M. D. (2007). Increasing reading motivation in elementary and middle school students through the use of multiple intelligence (Unpublished master's thesis). Saint Xavier University, Illinois, the United States.

Creswell, J. W. (2009). Research design: Qualitative and quantitative approaches. Thousand Oaks, CA: Sage Publications.

DeMeo, S. (2007). Constructing a graphic organizer in the classroom: Introductory students' perception of achievement using a decision map to solve aqueous acid-base equilibria problems. Journal of Chemical Education, 84(3), 540-546. http://dx.doi.org/10.1021/ed084p540

Dye, G. A. (2000). Graphic organizers to the rescue! Helping students link-and remember-information. Teaching Exceptional Children, 32(3), 72-76.

England, L. (1998). Promoting effective professional development in English language teaching (ELT). English Teaching Forum, 36(2), 18-23.

Eun, B. (2006). The impact of English as second language professional development program: A social cognitive approach (Unpublished doctoral dissertation). University of North Carolina, North Carolina, the United States.

Fisher, A. L. (2001). Implementing graphic organizer notebooks: The art and science of teaching content. Reading Teacher, 55(2), 116-120.

Gabl, K. A., Kaiser, K. L., Long, J. K., \& Roemer, J. L. (2007). Improving reading comprehension and fluency through the use of guided reading (Unpublished master's thesis). Saint Xavier University, Illinois, the United States.

Gil-Garcia, A., \& Villegas, J. (2003). Engaging minds, enhancing comprehension and constructing knowledge through visual representations. Paper presented at a conference on Word Association for Case Method Research and Application. Retrieved from http://www.eric.ed.gov/PDFS/ED480131.pdf

Goodson, L. C. (2000). Teaching and learning strategies for complex thinking skills. Paper presented at the National Convention of the Association for Educational Communications and Technology. Retrieved from http://www.eric.ed.gov/PDFS/ED455772.pdf

Gould, J., \& Gould, E. (1999). Four squares writing method for grades 1-3. Carthage, IL: Teaching and Learning Company.

Guskey, T. R. (2000). Evaluating professional development. Thousand Oaks, CA: Corwin Press.

Guskey, T. R. (2002). Professional development and teacher change. Teachers and Teaching: Theory and Practice, 8(3/4), 381-391.

Hawk, P. P. (1986). Using graphic organizers to increase achievement in middle school life science. Science Education, 70(1), 81-87. http://dx.doi.org/10.1002/sce.3730700110 
Ives, B. (2007). Graphic organizers applied to secondary algebra instruction for students with learning disorders. Learning Disabilities Research \& Practice, 22(2), 110-118.

Katayama, A. D., \& Robinson, D. H. (2000). Getting students partially involved in note-taking using graphic organizers. Journal of Experimental Education, 68(2), 119-133.

LeCompte, M. D., \& Schensul, J. J. (1999). Designing and conducting ethnographic research. Walnut Creek, CA: AltaMira.

Mackinnon, G. (2006). Contentious issues in science education: Building critical thinking patterns through two-dimensional concept mapping. Journal of Educational Multimedia and Hypermedia, 15(4), 433-455.

Marshall, C., \& Rossman, G. B. (2006). Design qualitative research. Thousand Oaks, CA: Sage Publications.

Merkley, D. M., \& Jefferies, D. (2000). Guidelines for implementing a graphic organizer. Reading Teacher, 54(4), 350-357.

Merriam, S. B. (1998). Qualitative research and case study applications in education. San Francisco, CA: Jossey-Bass.

Meyen, E. L., Vergason, G. A., \& Whelan, R. J. (1996). Strategies for teaching exceptional children in inclusive settings. Denver, CO: Love.

Nussbaum, E. M., \& Schraw, G. (2007). Promoting argument-counterargument integration in students' writing. Journal of Experimental Education, 76(1), 59-92.

Ogle, D. (1986). K-W-L: A teaching model that develops active reading of expository text. Reading Teacher, 39(6), 564-570.

Ogle, D. (2009). Creating contexts to inquiry: From KWL to PRC2. Knowledge Quest, 38(1), 56-61.

Olivia, P. F., \& Pawlas, G. E. (2001). Supervision for today's schools $\left(6^{\text {th }}\right.$ Ed). New York, NY: John Wiley \& Sons, Inc.

Robinson, D. H., Katayama, A. D., Beth, A., Odom, S., Hsieh, Y. P., \& Vanderveen, A. (2006). Increasing text comprehension and graphic note taking using a partial graphic organizer. Journal of Educational Research, 100(2), 103-111. http://dx.doi.org/10.3200/JOER.100.2.103-111

Roe, B. D., Stoodt, B. D., \& Burns, P. C. (1998). The content areas. Boston, MA: Houghton Mifflin.

Ruddell, M. R. (1997). Teaching content reading and writing. Boston, MA: Allyn \& Bacon.

Smith, J. J. (2002). The use of graphic organizers in vocabulary instruction (Unpublished master's thesis). Kean University, New Jersey, the United States.

Sparks, D. (1994). A paradigm shift in staff development. Journal of Staff Development, 15(4), 26-29.

Speck, M., \& Knipe, C. (2001). Why can't we get it right: Professional development in our schools. Thousand Oaks, CA: Corwin Press.

Stull, A. T., \& Mayer, R. E. (2007). Learning by doing versus by viewing: Three experimental comparisons of learner-generated versus author-provided graphic organizers. Journal of Education Psychology, 99(4), 808-820.

Teal, T. (2003). Strategies to enhance vocabulary development. ERIC Document 479128. Washington, DC: ERIC Clearinghouse on Teaching and Teacher Education. Retrieved from http://www.eric.ed.gov/PDFS/ED479128.pdf

Wallace, R., Pearman, C., Hail, C., \& Hurst, B. (2007). Writing for comprehension. Reading Horizons, 48(1), 41-56.

Williams, J. P., Hall, K. M., Lauer, K. D., Stafford, K. B., Desisto, L., \& deCani, J. S. (2005). Expository text comprehension in the primary grade classroom. Journal of Educational Psychology, 97(4), 538-550. http://dx.doi.org/10.1037/0022-0663.97.4.538

Wilson, S. M., \& Berne, J. (1999). Teacher learning and the acquisition of professional knowledge: An examination of research on contemporary professional development. Review of Research in Education, 24, 173-209.

Zollman, A. (2009). Students use graphic organizers to improve mathematical problem-solving communications. Middle School Journal, 41(2), 4-12. 